\title{
Perancangan Dan Pengembangan Aplikasi Sistem Informasi Monitoring Perkuliahan Dan Kehadiran Mahasiswa Berbasis Web
}

\author{
Rima Irmayani Rahmat, Prasetyo Wibowo Yunanto \\ Universitas Negeri Jakarta \\ rimairmayanirahmat@gmail.com,prasetyo.wy@unj.ac.id
}

\begin{abstract}
Abstrak
Penelitian ini bertujuan untuk membuat aplikasi berbasis web yang dapat memonitoring perkuliahan, penilaian mahasiswa secara rinci, dan kehadiran mahasiswa, sehingga dapat membantu bagian administrasi akademik, ketua program studi dan dosen dalam mengatasi masalah kehadiran dan penilaian mahasiswa yang sering kesulitan mendata sebagian mahasiswa yang hadir pada matakuliah yang sedang diampu dan informasi lainnya, karena kebanyakan informasi yang kurang lengkap, input penilaian dan kehadiran yang masih manual dan sulit diakses melalui web. Penelitian dilakukan di Jurusan Teknik Elektro Fakultas Teknik Universitas Negeri Jakarta sejak bulan Maret 2015 hingga Juni 2015. Metode yang digunakan dalam penelitian ini adalah metode penelitian dan pengembangan (Research and Development atau $R \& D$ ) dengan model pengembangan perangkat lunak prototype. Secara keseluruhan terdapat 3 tahap dalam proses penelitian dan pengembangan ini yaitu penelitian awal, pengembangan produk dan pengujian serta revisi produk. Penelitian awal dilakukan guna untuk mengidentifikasi permasalahan dan mencari solusi dalam pemecahan masalah tersebut. Proses pengembangan produk meliputi tahap analisis, perancangan, implementasi dan pengujian fungsional. Hasil uji coba menunjukkan bahwa setelah melalui tahapan-tahapan, aplikasi berbasis web dapat diimplementasi pada sistem informasi dan cocok untuk menghasilkan aplikasi web yang dapat melakukan penginputan kehadiran dan penilaian mahasiswa Program Studi Pendidikan Teknik Informatika dan Komputer Jurusan Teknik Elektro Fakultas Teknik Universitas Negeri Jakarta berdasarkan matakuliah yang diampu oleh dosen. Bentuk akhir dari prototype adalah sebuah sistem monitoring perkuliahan berbasis web yang dapat dipergunakan oleh bagian administrasi akademik, ketua program studi, dosen dan penanggung jawab kelas dalam penilaian dan evaluasi terhadap mahasiswa.
\end{abstract}

Kata kunci: pengembangan, sistem, informasi, monitoring kehadiran, web

\section{Pendahuluan}

Proses belajar mengajar atau pembelajaran merupakan suatu kegiatan melaksanakan kurikulum dalam lembaga pendidikan agar mahasiswa dapat mencapai tujuan yang telah ditetapkan oleh aturan akademik. Tujuan pendidikan pada dasarnya mengantarkan para mahasiswa menuju perubahan tingkah laku baik intelektual, moral, maupun sosial budaya.

Evaluasi dalam dunia pendidikan merupakan suatu hal yang sudah sering ditemui. Meskipun kini memiliki makna yang lebih luas, namun pada awalnya pengertian evaluasi pendidikan selalu dikaitkan dengan prestasi belajar siswa. Definisi yang pertama dikembangkan oleh Ralph Tyler mengatakan bahwa evaluasi merupakan sebuah proses pengumpulan data untuk menentukan sejauh mana, dalam hal apa, dan bagian mana tujuan pendidikan sudah tercapai. ${ }^{[1]}$

Besarnya jumlah civitas akademik di lingkungan Program Studi Pendidikan Teknik Informatika dan Komputer Jurusan Teknik Elektro Fakultas Teknik Universitas Negeri Jakarta ini membawa konsekuensi serius terhadap pengendalian, pengolahan dan pengoperasian layanan monitoring perkuliahan khususnya di Program Studi Pendidikan Teknik Informatika dan Komputer Jurusan Teknik Elektro Fakultas Teknik Universitas Negeri Jakarta. Ditambah banyaknya program studi yang ada di Universitas Negeri Jakarta sehingga secara spesifik kondisi ini akan sangat berpengaruh terhadap kualitas layanan informasi mahasiswa dan transparansi nilai seperti layanan untuk Kehadiran Online, Penginputan Nilai Tugas, UTS dan UAS Mahasiswa, kurangnya pengontrolan 4 
terhadap kehadiran mahasiswa, nilai tugas harian, uts, dan uas yang harus dibuat oleh setiap dosen dan lain sebagainya. Untuk menjamin kualitas layanan informasi absensi perkuliahan ini, baik yang mengenai isi, bentuk dan keakuratan data, diperlukan penanganan administrasi akademik dengan baik dan benar. Namun demikian mengingat besarnya jumlah transaksi data yang harus ditangani setiap semester, serta besarnya tanggung jawab yang diemban oleh unit bagian ini, maka perlu diupayakan pembenahan sistem yang berjalan saat ini yang disesuaikan dengan kebutuhan dimasa mendatang.

Menurut Peraturan Menteri Pendidikan Nasional Nomor 61 Tahun 2009 tentang Pemberian Kuasa dan Delegasi Wewenang Pelaksanaan Kegiatan Administrasi Kepegawaian Kepada Pejabat Tertentu di Lingkungan Kementerian Pendidikan Nasional. ${ }^{[2]}$ Absensi adalah suatu kegiatan atau rutinitas yang dilakukan oleh pegawai untuk membuktikan dirinya hadir atau tidak hadir dalam bekerja disuatu instansi mengatakan bahwa absensi adalah sebuah kegiatan pengambilan data guna mengetahui jumlah kehadiran pada suatu acara. Tak terlepas juga dari kegiatan belajar mengajar dimana daftar absensi akan memberikan banyak fungsi yang penting yang akan berkaitan dengan kemungkinan mahasiswa untuk mengikuti ujian. Namun kegiatan absensi ini masih dilakukan dengan manual menggunakan kertas dengan tanda tangan sebagai validitas data yang memiliki banyak sekali kekurangan. Tidak validnya data karena pengisian data yang tak sesuai, data loss karena hilangnya atau rusaknya data bahkan kurangnya efisiensi karena waktu dalam penggalian informasi, koreksi data hingga validasi informasi membutuhkan waktu yang lama. Informasi dari absensi ini sendiri akan digunakan untuk berbagai hal yang berhubungan dengan pihak kegiatan belajar mengajar hingga untuk pihak mahasiswa itu sendiri.

\section{Dasar Teori}

Pada bagian ini diuraikan landasan teoretis yang berhubungan dengan penelitian atau perancangan yang dilakukan.

\subsection{Sistem}

Sistem adalah sekumpulan elemen yang saling terkait atau terpadu yang dimaksudkan untuk mencapai suatu tujuan ${ }^{[3]}$

\subsection{Informasi}

McFadden, dkk (1999) mendefinisikan informasi sebagai data yang telah diproses sedemikian rupa sehingga meningkatkan pengetahuan seseorang yang menggunakan data tersebut.

\subsection{Sistem Informasi}

Sistem informasi adalah kombinasi antara prosedur kerja, informasi, orang dan teknologi informasi yang diorganisasikan untuk mencapai tujuan dalam sebuah organisasi (Alter dalam Abdul Kadir, 2003:11). ${ }^{[3]}$

\subsection{Sistem Informasi Monitoring}

Sistem informasi monitoring perkuliahan, jurusan dapat mengetahui sejauh mana proses perkuliahan yang telah berlangsung beserta evaluasinya dalam usaha manajemen keseluruhan data proses kuliah yang telal dilakukan dalam rangka perbaikan mutu perguruan tinggi dalam bidang akademis.

\section{Metodologi}

\subsection{Metodologi Penelitian}

Menurut Borg dan Gall dalam Sudarna (2011:49) yang dimaksud dengan metode penelitian dan pengembangan adalah "a process used develop and validates educational product”.

Metode penelitian dan pengembangan adalah metode penelitian yang digunakan untuk menghasilkan produk tertentu, dan menguji keefektifan produk tersebut. ${ }^{[4]}$

\subsection{Metodologi Pengembangan Perangkat Lunak}

\subsection{Metode prototype}

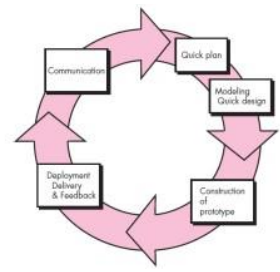

Dalam melakukan perancangan sistem yang akan dikembangkan dapat menggunakan metode prototype. ${ }^{[5]}$ Metode ini cocok digunakan untuk mengembangkan sebuah perangkat yang akan dikembangkan kembali. Metode ini dimulai dengan kebutuhan pengguna, dalam hal ini pengguna dari perangkat yang dikembangkan adalah bagian administrasi akademik, dosen, ketua program studi dan penanggung jawab kelas (mahasiswa). Kemudian membuat sebuah rancangan yang selanjutnya dievaluasi kembali sebelum diproduksi secara benar.

\subsection{Perancangan User Interface}

Perancangan user interface dilakukan dengan membuat gambaran sketsa halaman muka web, proses ini dilakukan dengan menggunakan software Adobe Photoshop CS5 dan PhotoScape V3.6.3. Adapun bentuk dari rancangan user interface secara umum ditunjukkan sebagai berikut:

a. Rancangan Tampilan Log in Pada gambar 3.2 berupa halaman log in terdapat fitur:

1. Input username, user menginput sesuai username. 
2. Input password, user menginput halaman admin password.

3. Button login, untuk melakukan login.

4. Hyperlink lupa password, user dapat mengetahui password.

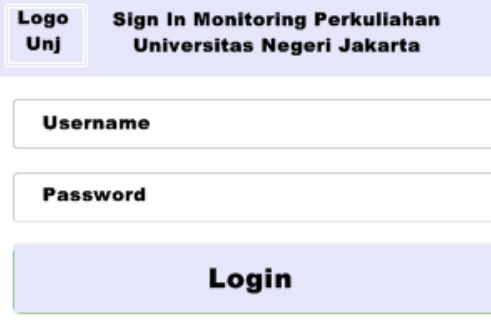

Lupa Password?

Gambar 3.2. Rancangan User Interface tampilan menu $\log$ in

b. Rancangan Tampilan Halaman Admin Pada gambar 3.3 berupa halaman admin terdapat fitur:

1. Profile, admin dapat mengubah nama akun, foto profile, dan update security question.

2. Password, admin dapat mengubah password.

3. Home, agenda kegiatan akademik maupun non akademik.

4. Matakuliah, matakuliah berisi daftar hadir perkuliahan dosen, daftar hadir perkuliahan mahasiswa, dan penilaian. Admin hanya dapat mencetak form 05 daftar hadir perkuliahan dosen, form 06 daftar hadir perkuliahan dan penilaian, dan silabus rumusan penilaian.

5. Master data, admin dapat menginput agenda, menginput instrument evaluasi pertanyaan, daftar akun, menginput dosen, menginput mahasiswa, menginput semester, menginput jadwal matakuliah, menginput pengampu matakuliah, menginput mahasiswa ke matakuliah.

6. Hubungi kami, kontak yang dapat dihubungi.

7. Logout, admin keluar dari sistem.

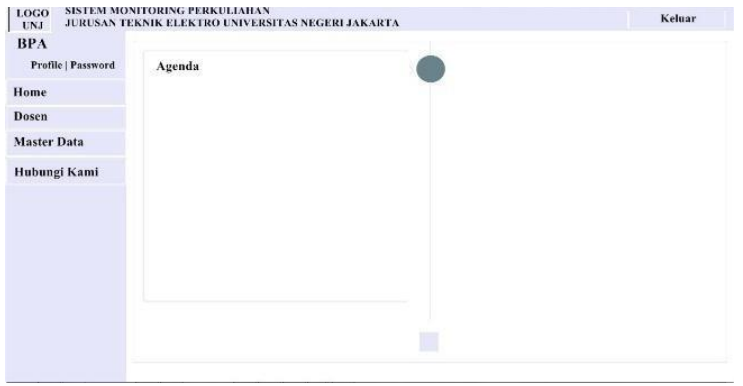

Gambar 3.3 Rancangan User Interface tampilan 
c. Rancangan Tampilan Halaman Dosen Pada gambar 3.4 berupa halaman dosen terdapat fitur:

1. Profile, dosen dapat mengubah nama akun, foto profile, dan update security question.

2. Password, dosen dapat mengubah password.

3. Home, agenda kegiatan akademik maupun non akademik.

4. Dosen, di dalam menu dosen terdapat fitur:

a. Rumusan penilaian, dosen dapat menginput rumusan penilaian.

b. Form 05, dosen dapat menginput form 05 daftar hadir perkuliahan dosen.

c. Form 06 Ebook, dosen dapat menginput electronic book.

d. Form 06 Kehadiran, dosen dapat menginput daftar kehadiran perkuliahan.

e. Form tugas, dosen dapat menginput tugas.

f. Form 06 penilaian tugas, dosen dapat menginput nilai tugas.

g. Form 06 penilaian praktik, dosen dapat menginput nilai praktik.

h. Form 06 penilaian ujian tengah semester, dosen dapat menginput nilai ujian tengah semester.

i. Form 06 penilaian ujian akhir semester, dosen dapat menginput nilai ujian akhir semester.

j. Form 06 nilai akhir, otomatis sistem akan menghitung nilai sesuai dengan bobot penilaian yang diinput oleh dosen dengan rumusan penilaian.

5. Hubungi kami, kontak yang kontak yang dapat dihubungi.

6. Logout, dosen keluar dari sistem.

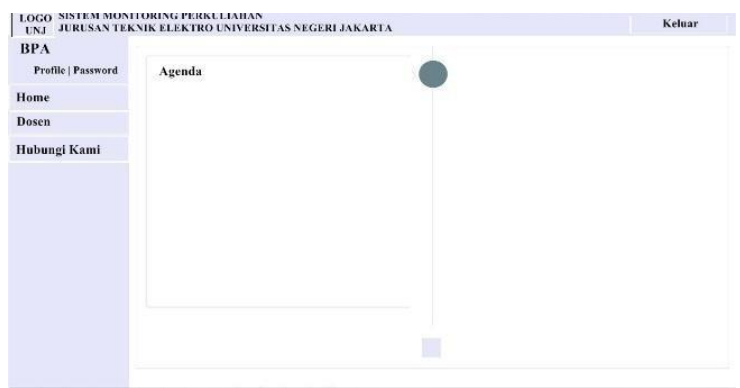

Gambar 3.4 Rancangan User Interface tampilan halaman dosen

d. Rancangan Tampilan Halaman

Ketua Program Studi

Pada gambar 3.5 berupa halaman ketua

program studi terdapat fitur: 
1. Profile, ketua program studi dapat mengubah nama akun, foto profile, dan update security question.

2. Password, ketua program studi dapat mengubah password.

3. Home, agenda kegiatan akademik maupun non akademik.

4. Matakuliah, di dalam menu matakuliah ketua program studi hanya dapat mengkonfirmasi forn 05 daftar hadir perkuliahan dosen, mengunduh silabus, mengunduh form 05 daftar hadir perkuliahan dosen, form 06 daftar hadir perkuliahan dan penilaian.

5. Hubungi kami, kontak yang kontak yang dapat dihubungi.

6. Logout, ketua program studi keluar dari sistem

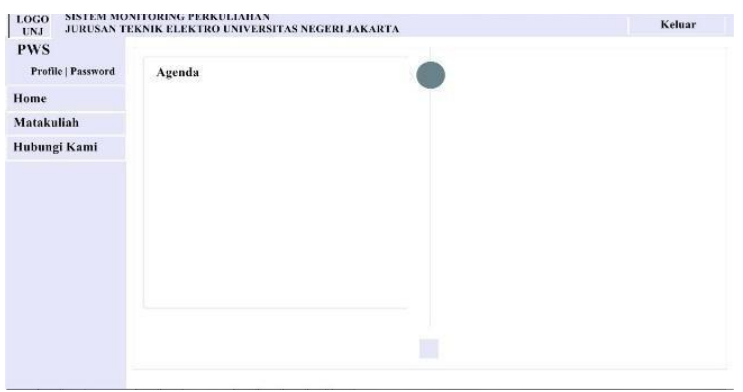

Gambar 3.5 Rancangan User Interface tampilan halaman ketua program studi

e. Rancangan Tampilan Halaman Penanggung Jawab Kelas

Pada gambar 3.6 berupa halaman penanggung jawab kelas terdapat fitur:

1. Profile, penanggung jawab kelas dapat mengubah nama akun, foto profile, dan update security question.

2. Password, penanggung jawab kelas dapat mengubah password.

3. Home, agenda kegiatan akademik maupun non akademik.

4. Matakuliah, di dalam menu matakuliah penanggung jawab kelas hanya dapat mengkonfirmasi forn 05 daftar hadir perkuliahan dosen, mengunduh silabus, mengunduh form 06 electronic book dan mengunduh form 06 tugas.

5. Hubungi kami, kontak yang kontak yang dapat dihubungi.

6. Logout, penaggung jawab kelas keluar dari sistem.

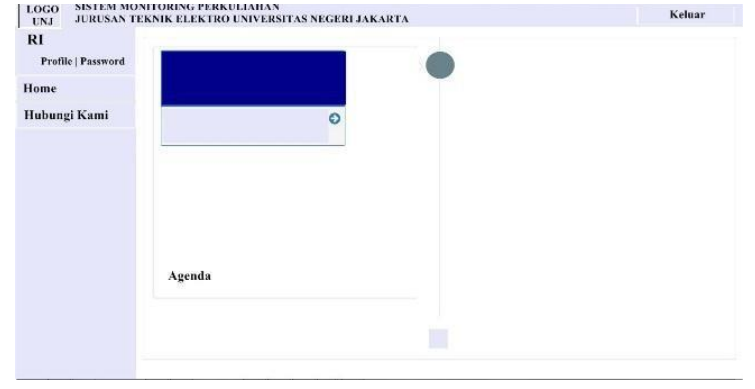

Gambar 3.6 Rancangan User Interface tampilan halaman penanggung jawab kelas

\subsection{Teknik Pengujian}

a. User Acceptance Test

User Acceptance Test (UAT) atau Uji Penerimaan Pengguna adalah suatu proses pengujian oleh pengguna yang dimaksudkan untuk menghasilkan dokumen yang dijadikan bukti bahwa software yang telah dikembangkan telah dapat diterima oleh pengguna, apabila hasil pengujian (testing) sudah bisa dianggap memenuhi kebutuhan dari pengguna.

\section{b.Teknik Uji Fungsional}

Teknik pengujian pada aplikasi digunakan untuk membuktikan apakah seluruh kebutuhan fungsional yang diinginkan bekerja dengan baik dan memastikan apakah masih ada atau tidak kesalahan pada aplikasi. Selain itu, pengujian ini bertujuan untuk menjamin kualitas aplikasi yaitu dengan meninjau spesifikasi, desain, dan pengkodean aplikasi yang dibuat.

\subsection{Pedoman Wawancara}

Pedoman wawancara digunakan sebagai acuan pada tahap wawancara dengan bagian akademik administrasi Jurusan Teknik Elektro, Ketua Program Studi, Dosen dan Mahasiswa Program Studi Pendidikan Teknik Informatika dan Komputer Jurusan Teknik Elektro Fakultas Teknik Universitas Negeri Jakarta sebagai responden. Penggunaan pedoman wawancara dilakukan agar pertanyaan yang diajukan tidak terlalu meluas dan sesuai dengan kebutuhan penelitian.

\section{Hasil dan Analisis}

Pengujian sistem menggunakan metode black box dengan menguji sistem secara fungsional dan melihat output yang dihasilkan sistem. Hasil penelitian memberikan hasil sebagai berikut:

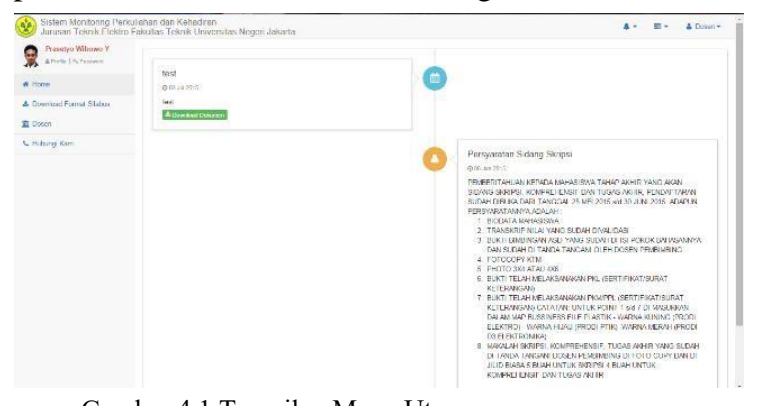




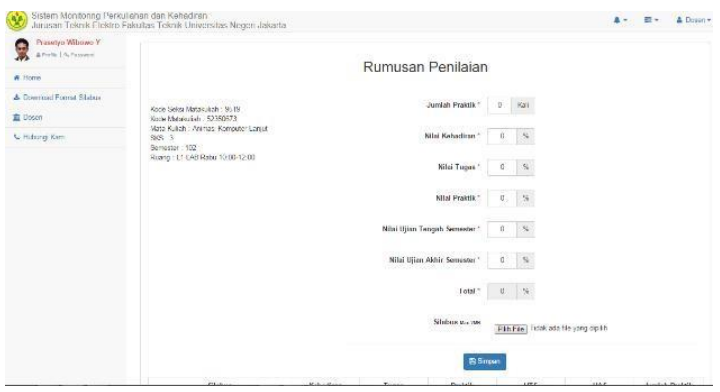

Gambar 4.2 Tampilan Rumusan Penilaian

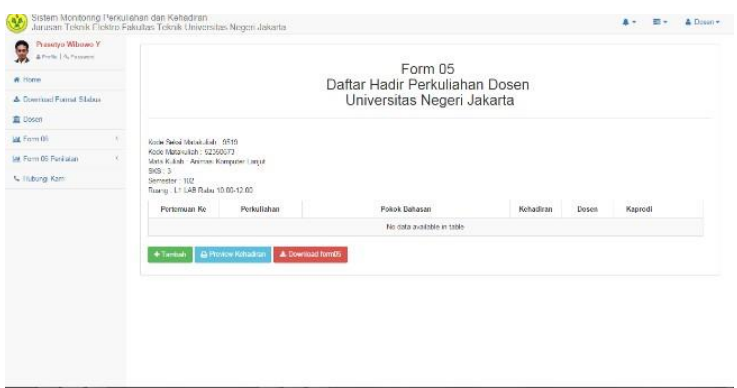

Gambar 4.3 Tampilan Form 05 Daftar Hadir

Perkuliahan Dosen

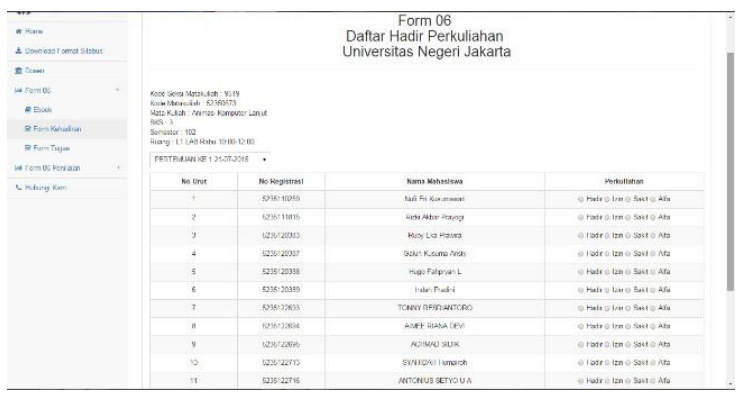

Gambar 4.4 Tampilan Form 06 Daftar Hadir

Perkuliahan

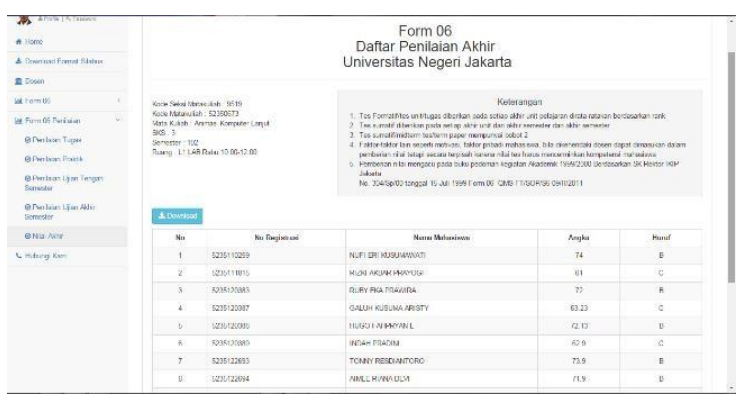

Gambar 4.5 Tampilan Form 06 Daftar Penilaian Akhir

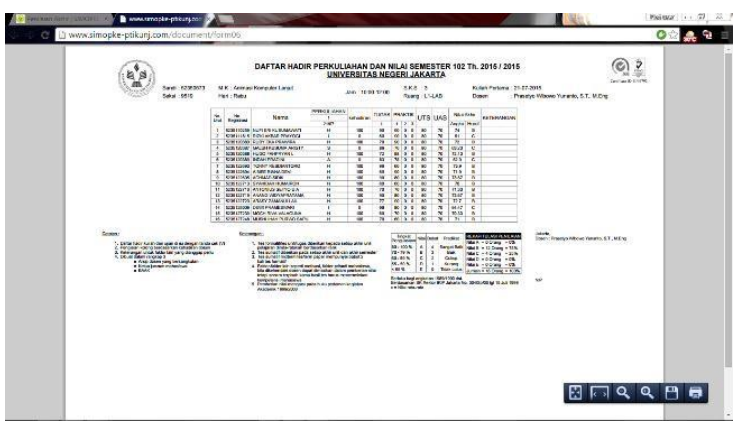


Tabel 4.1Hasil Pengujian Fungsional pada

Menu Dosen

\begin{tabular}{|c|l|c|c|}
\hline No & \multicolumn{1}{|c|}{ Skenario Proses } & $\begin{array}{c}\text { Sistem } \\
\text { Bekerj } \\
\mathbf{a} \\
\text { (Ya/Tid }\end{array}$ & Ket \\
\hline 1. & $\begin{array}{l}\text { Hyperlink ke halaman } \\
\text { Dosen berfungsi. }\end{array}$ & Ya & - \\
\hline 2. & $\begin{array}{l}\text { Selector untuk } \\
\text { memilih semester yang } \\
\text { berjalan berfungsi } \\
\text { dengan benar. }\end{array}$ & Ya & - \\
\hline 4. & $\begin{array}{l}\text { Selector untuk } \\
\text { memilih matakuliah } \\
\text { yang diampu oleh } \\
\text { dosen berfungsi } \\
\text { dengan benar. }\end{array}$ & Ya & - \\
\hline 5. & $\begin{array}{l}\text { Hyperlink ke halaman } \\
\text { rumusan penilaian } \\
\text { berfungsi dengan } \\
\text { benar }\end{array}$ & Ya & - \\
\hline
\end{tabular}

Tabel 4.2 Hasil Pengujian Fungsional pada Input Rumusan Penilaian

\begin{tabular}{|c|c|c|c|}
\hline No. & Skenario Proses & $\begin{array}{c}\text { Sistem } \\
\text { Bekerj } \\
\mathbf{a} \\
\text { (Ya/Tid }\end{array}$ & Ket \\
\hline 1. & $\begin{array}{l}\text { Hyperlink ke halaman } \\
\text { input rumusan } \\
\text { penilaian berfungsi }\end{array}$ & $\mathrm{Ya}$ & - \\
\hline 2. & $\begin{array}{l}\text { Halaman } \\
\text { menampilkan rumusan } \\
\text { penilaian dengan benar } \\
\text { sesuai dengan kode } \\
\text { seksi matakuliah, kode } \\
\text { matakuliah, } \\
\text { matakuliah, semester, } \\
\text { sks dan lokasi. }\end{array}$ & $\mathrm{Ya}$ & - \\
\hline 3. & $\begin{array}{l}\text { Textfield untuk input } \\
\text { jumlah praktik, nilai } \\
\text { kehadiran, nilai } \\
\text { praktik, nilai tugas, } \\
\text { nilai praktik, nilai } \\
\text { ujian tengah semester } \\
\text { dan nilai ujian akhir } \\
\text { semester berfungsi. }\end{array}$ & $\mathrm{Ya}$ & - \\
\hline 4. & $\begin{array}{l}\text { Total prosentase } \\
\text { penilaian berfungsi. }\end{array}$ & Ya & - \\
\hline 5. & $\begin{array}{l}\text { Button pilih file untuk } \\
\text { upload silabus } \\
\text { berfungsi. }\end{array}$ & Ya & - \\
\hline 6. & $\begin{array}{l}\text { Button simpan pada } \\
\text { rumusan penilaian } \\
\text { berfungsi dengan } \\
\text { benar }\end{array}$ & $\mathrm{Ya}$ & - \\
\hline 7. & $\begin{array}{l}\text { Button simpan tidak } \\
\text { dapat ditekan apabila } \\
\text { user menginput }\end{array}$ & $\mathrm{Ya}$ & - \\
\hline
\end{tabular}




\begin{tabular}{|c|c|c|c|}
\hline No. & Skenario Proses & $\begin{array}{c}\text { Sistem } \\
\text { Bekerj } \\
\quad \mathbf{a} \\
\text { (Ya/Tid }\end{array}$ & Ket \\
\hline & $\begin{array}{l}\text { prosentase penilaian } \\
\text { melebihi } 100 \%\end{array}$ & & \\
\hline 8. & $\begin{array}{l}\text { Button simpan tidak } \\
\text { dapat ditekan apabila } \\
\text { user tidak memasukan } \\
\text { silabus. }\end{array}$ & $\mathrm{Ya}$ & - \\
\hline 9. & $\begin{array}{l}\text { Hyperlink ke halaman } \\
\text { form } 05 \text { daftar hadir } \\
\text { perkuliahan dosen } \\
\text { berfungsi. }\end{array}$ & $\mathrm{Ya}$ & - \\
\hline
\end{tabular}

Tabel 4.3 Hasil Pengujian Fungsional pada Input Form 05 Daftar Hadir Perkuliahan Dosen

\begin{tabular}{|c|c|c|c|}
\hline No. & Skenario Proses & $\begin{array}{c}\text { Sistem } \\
\text { Bekerj } \\
\quad \mathbf{a} \\
\text { (Ya/Tid }\end{array}$ & Ket \\
\hline 1. & $\begin{array}{l}\text { Hyperlink ke halaman } \\
\text { form } 05 \text { daftar hadir } \\
\text { perkuliahan dosen } \\
\text { berfungsi. }\end{array}$ & $\mathrm{Ya}$ & - \\
\hline 2. & $\begin{array}{l}\text { Halaman } \\
\text { menampilkan form } 05 \\
\text { daftar hadir } \\
\text { perkuliahan dosen } \\
\text { dengan benar sesuai } \\
\text { dengan kode seksi } \\
\text { matakuliah, kode } \\
\text { matakuliah, } \\
\text { matakuliah, semester, } \\
\text { sks dan lokasi. }\end{array}$ & $\mathrm{Ya}$ & - \\
\hline 3. & $\begin{array}{l}\text { Tabel daftar hadir } \\
\text { perkuliahan terdiri dari } \\
\text { pertemuan ke-, tanggal } \\
\text { perkuliahan, pokok } \\
\text { bahasan, jumlah } \\
\text { mahasiswa, konfirmasi } \\
\text { dosen dan konfirmasi } \\
\text { ketua program studi. }\end{array}$ & $\mathrm{Ya}$ & - \\
\hline 4. & $\begin{array}{l}\text { Button tambah untuk } \\
\text { mengisi form } 05 \text { daftar } \\
\text { hadir perkuliahan } \\
\text { dosen berfungsi. }\end{array}$ & $\mathrm{Ya}$ & - \\
\hline 5 . & $\begin{array}{l}\text { Muncul pop up pada } \\
\text { saat tambah form } 05 \\
\text { daftar hadir } \\
\text { perkuliahan dosen. }\end{array}$ & $\mathrm{Ya}$ & - \\
\hline 6. & $\begin{array}{l}\text { Textfield untuk input } \\
\text { pokok bahasan } \\
\text { berfungsi. }\end{array}$ & Ya & - \\
\hline 7. & $\begin{array}{l}\text { Fungsi kalender } \\
\text { perkuliahan tidak } \\
\text { dapat diupdate selain } \\
\text { dari sistem }\end{array}$ & $\mathrm{Ya}$ & - \\
\hline
\end{tabular}

\begin{tabular}{|c|c|c|c|}
\hline No. & Skenario Proses & $\begin{array}{c}\text { Sistem } \\
\text { Bekerj } \\
\mathbf{a} \\
\text { (Ya/Tid }\end{array}$ & Ket \\
\hline 8. & $\begin{array}{l}\text { Jumlah mahasiswa } \\
\text { otomatis terhitung dari } \\
\text { form } 06 \text { kehadiran } \\
\text { mahasiswa }\end{array}$ & $\mathrm{Ya}$ & - \\
\hline 9. & $\begin{array}{l}\text { Selectbox konfirmasi } \\
\text { dosen pengampu } \\
\text { berfungsi. }\end{array}$ & $\mathrm{Ya}$ & - \\
\hline 10. & $\begin{array}{l}\text { Pertemuan ke- tidak } \\
\text { dapat diubah oleh } \\
\text { user. }\end{array}$ & $\mathrm{Ya}$ & - \\
\hline 11. & $\begin{array}{l}\text { Button update pada } \\
\text { form } 05 \text { daftar hadir } \\
\text { perkuliahan dosen } \\
\text { berfungsi dengan } \\
\text { benar. }\end{array}$ & $\mathrm{Ya}$ & - \\
\hline 12. & $\begin{array}{l}\text { Button Edit dan hapus } \\
\text { muncul setelah } \text { user } \\
\text { menekan button } \\
\text { simpan. }\end{array}$ & $\mathrm{Ya}$ & - \\
\hline 13. & $\begin{array}{l}\text { Button edit pada form } \\
05 \text { daftar hadir } \\
\text { perkuliahan dosen } \\
\text { berfungsi dengan } \\
\text { benar. }\end{array}$ & $\mathrm{Ya}$ & - \\
\hline 14. & $\begin{array}{l}\text { Muncul pop up pada } \\
\text { saat edit form } 05 \\
\text { daftar hadir } \\
\text { perkuliahan dosen. }\end{array}$ & $\mathrm{Ya}$ & - \\
\hline 15 . & $\begin{array}{l}\text { Button update pada } \\
\text { saat mengedit form } 05 \\
\text { daftar hadir } \\
\text { perkuliahan dosen } \\
\text { berfungsi. }\end{array}$ & $\mathrm{Ya}$ & - \\
\hline 16. & $\begin{array}{l}\text { Button hapus pada } \\
\text { form } 05 \text { daftar hadir } \\
\text { perkuliahan dosen } \\
\text { berfungsi dengan } \\
\text { benar. }\end{array}$ & $\mathrm{Ya}$ & - \\
\hline 17. & $\begin{array}{l}\text { Pesan pemberitahuan } \\
\text { muncul ketika } \text { user } \\
\text { menekan button hapus. }\end{array}$ & $\mathrm{Ya}$ & - \\
\hline 18. & $\begin{array}{l}\text { Button Edit dan hapus } \\
\text { hilang setelah } \text { user } \\
\text { menekan button hapus. }\end{array}$ & $\mathrm{Ya}$ & - \\
\hline 19. & $\begin{array}{l}\text { Button download pada } \\
\text { penambahan form } 05 \\
\text { berfungsi. }\end{array}$ & $\mathrm{Ya}$ & - \\
\hline 20. & $\begin{array}{l}\text { Hasil download form } \\
05 \text { daftar hadir } \\
\text { perkuliahan dosen } \\
\text { format pdf. }\end{array}$ & $\mathrm{Ya}$ & - \\
\hline 21. & $\begin{array}{l}\text { User pindah ke } \\
\text { halaman tampilan } \\
\text { form } 05 \text { daftar hadir } \\
\text { perkuliahan dosen }\end{array}$ & $\mathrm{Ya}$ & - \\
\hline
\end{tabular}




\begin{tabular}{|c|c|c|}
\hline No. & Skenario Proses & $\begin{array}{c}\text { Sistem } \\
\text { Bekerj } \\
\mathbf{a} \\
\text { (Ya/Tid }\end{array}$ \\
\hline & $\begin{array}{l}\text { apabila menekan } \\
\text { button Simpan. }\end{array}$ & \\
\hline 22 & $\begin{array}{l}\text { User kembali ke } \\
\text { halaman tampilan } \\
\text { form } 05 \text { daftar hadir } \\
\text { perkuliahan dosen } \\
\text { apabila menekan } \\
\text { button Batal. }\end{array}$ & Ya \\
\hline
\end{tabular}

Tabel 4.4 Hasil Pengujian Fungsional pada Menu Input Form 06 Daftar Hadir Perkuliahan

\begin{tabular}{|c|c|c|c|}
\hline No. & Skenario Proses & $\begin{array}{c}\text { Sistem } \\
\text { Bekerj } \\
\text { a } \\
\text { (Ya/Tid }\end{array}$ & Ket \\
\hline & $\begin{array}{l}\text { registrasi mahasiswa } \\
\text { tersebut Alfa. }\end{array}$ & & \\
\hline 9. & $\begin{array}{l}\text { Data no registrasi } \\
\text { mahasiswa, nama } \\
\text { mahasiswa, } \\
\text { perkuliahan tidak akan } \\
\text { muncul apabila } \text { user } \\
\text { tidak memilih } \\
\text { pertemuan ke- }\end{array}$ & $\mathrm{Ya}$ & - \\
\hline
\end{tabular}

Tabel 4.5 Hasil Pengujian Fungsional pada Menu Input Form 06 Penilaian Akhir 


\begin{tabular}{|c|c|c|c|}
\hline No. & Skenario Proses & $\begin{array}{c}\text { Sistem } \\
\text { Bekerj } \\
\quad \mathbf{a} \\
\text { (Ya/Tid }\end{array}$ & Ket \\
\hline 1. & $\begin{array}{l}\text { Hyperlink ke halaman } \\
\text { form } 06 \text { daftar hadir } \\
\text { perkuliahan berfungsi. }\end{array}$ & $\mathrm{Ya}$ & - \\
\hline 2. & $\begin{array}{l}\text { Halaman } \\
\text { menampilkan form } 06 \\
\text { daftar hadir } \\
\text { perkuliahan dengan } \\
\text { benar sesuai dengan } \\
\text { kode seksi matakuliah, } \\
\text { kode matakuliah, } \\
\text { matakuliah, semester, } \\
\text { sks dan lokasi. }\end{array}$ & $\mathrm{Ya}$ & - \\
\hline 3. & $\begin{array}{l}\text { Tabel daftar hadir } \\
\text { perkuliahan terdiri dari } \\
\text { no registrasi, nama } \\
\text { mahasiswa dan } \\
\text { perkuliahan. }\end{array}$ & $\mathrm{Ya}$ & - \\
\hline 4. & $\begin{array}{l}\text { Select option } \\
\text { pertemuan ke- } \\
\text { berfungsi dengan } \\
\text { benar }\end{array}$ & $\mathrm{Ya}$ & - \\
\hline 5. & $\begin{array}{l}\text { Radio button pada } \\
\text { input perkuliahan } \\
\text { berfungsi. }\end{array}$ & $\mathrm{Ya}$ & - \\
\hline 6. & $\begin{array}{l}\text { Button simpan pada } \\
\text { daftar hadir } \\
\text { perkuliahan berfungsi } \\
\text { dengan benar. }\end{array}$ & $\mathrm{Ya}$ & - \\
\hline 7. & $\begin{array}{l}\text { Button preview } \\
\text { kehadiran berfungsi } \\
\text { dengan benar. }\end{array}$ & $\mathrm{Ya}$ & - \\
\hline 8. & $\begin{array}{l}\text { Sistem akan } \\
\text { merandom perkuliahan } \\
\text { apabila } \text { user lupa } \\
\text { mengabsensi no } \\
\text { registrasi mahasiswa } \\
\text { dan langsung menekan } \\
\text { button simpan maka } \\
\text { perkuliahan no }\end{array}$ & $\mathrm{Ya}$ & - \\
\hline
\end{tabular}

\begin{tabular}{|c|c|c|c|}
\hline No. & Skenario Proses & $\begin{array}{c}\text { Sistem } \\
\text { Bekerj } \\
\mathbf{a} \\
\text { (Ya/Tid }\end{array}$ & Ket \\
\hline 1. & $\begin{array}{l}\text { Hyperlink ke halaman } \\
\text { form } 06 \text { daftar } \\
\text { penilaian akhir } \\
\text { berfungsi. }\end{array}$ & $\mathrm{Ya}$ & - \\
\hline 2. & $\begin{array}{l}\text { Halaman } \\
\text { menampilkan form } 06 \\
\text { daftar penilaian akhir } \\
\text { dengan benar sesuai } \\
\text { dengan kode seksi } \\
\text { matakuliah, kode } \\
\text { matakuliah, } \\
\text { matakuliah, semester, } \\
\text { sks dan lokasi. }\end{array}$ & Ya & - \\
\hline 3. & $\begin{array}{l}\text { Tabel form } 06 \\
\text { penilaian ujian akhir } \\
\text { semester terdiri dari no } \\
\text { registrasi, nama } \\
\text { mahasiswa, penilaian } \\
\text { ujian akhir dengan } \\
\text { angka dan huruf. }\end{array}$ & Ya & - \\
\hline 4. & $\begin{array}{l}\text { Hyperlink ke halaman } \\
\text { form } 06 \text { daftar } \\
\text { penilaian akhir tidak } \\
\text { aktif apabila dosen } \\
\text { belum menginput } \\
\text { penilaian ujian tengah } \\
\text { semester. }\end{array}$ & $\mathrm{Ya}$ & - \\
\hline 5. & $\begin{array}{l}\text { Hyperlink ke halaman } \\
\text { form } 06 \text { daftar } \\
\text { penilaian akhir tidak } \\
\text { aktif apabila dosen } \\
\text { belum menginput } \\
\text { penilaian ujian akhir } \\
\text { semester }\end{array}$ & $\mathrm{Ya}$ & - \\
\hline 6. & $\begin{array}{l}\text { Button download pada } \\
\text { form } 06 \text { penilaian } \\
\text { akhir berfungsi dengan } \\
\text { benar. }\end{array}$ & $\mathrm{Ya}$ & - \\
\hline 7. & $\begin{array}{l}\text { Hasil dari download } \\
\text { form } 06 \text { kehadiran dan }\end{array}$ & $\mathrm{Ya}$ & - \\
\hline
\end{tabular}




\begin{tabular}{|l|l|l|l|}
\hline No. & \multicolumn{1}{|c|}{ Skenario Proses } & $\begin{array}{c}\text { Sistem } \\
\text { Bekerj } \\
\mathbf{a} \\
(\text { Ya/Tid }\end{array}$ & Ket \\
\hline & $\begin{array}{l}\text { penilaian mahasiswa } \\
\text { berformat pdf. }\end{array}$ & & \\
\hline
\end{tabular}

\subsection{Implementasi Sistem Monitoring}

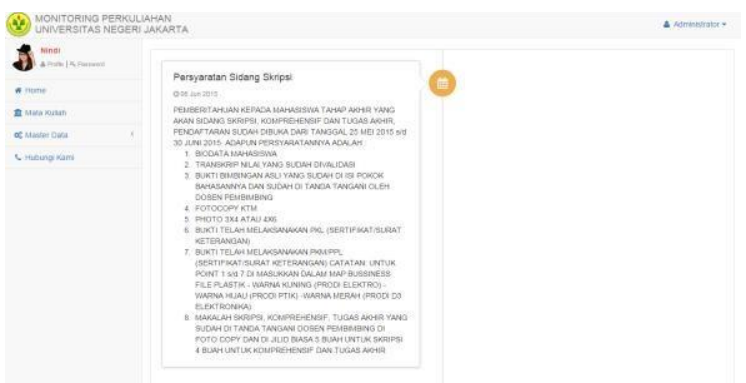

Gambar 4.1 Implementasi Sistem Monitoring Perkuliahan

\subsection{Pembahasan Tampilan User Interface}

Tampilan website sistem informasi monitoring perkuliahan dan kehadiran dibuat dengan dominan warna abu-abu, kuning dan putih. Warna abu-abu diambil karna warna abu-abu perpaduan dari dua warna hitam dan putih sehingga melambangkan kesatuan antara mahasiswa dengan mahasiswa, serta mahasiswa dengan dosen, dan staff. Warna kuning juga diambil dari warna logo Universitas Negeri Jakarta. Warna putih dipilih sebagai warna netral yang dapat mempermudah pengguna dalam monitoring perkuliahan dan kehadiran mahasiswa.

Dalam membuat tampilan yang dinamis dan responsif terhadap alat apapun, peneliti menggunakan bahasa pemrograman HTML, CSS, Javascript jQuery v1.3.0, jQuery-ui, serta menggunakan CSS template dari Bootstrap.

Untuk jenis tulisan, peneliti menggunakan jenis tulisan dengan font-family: Sans Serif yang memberikan kesan lugas, jelas, informatif dan formal. Selain itu, navigasi halaman website dibuat seminim mungkin untuk memudahkan user melakukan monitoring perkuliahan dan kehadiran tanpa ada kesalahan teknis.

\subsection{Pembahasan Hasil Pengujian Fungsional}

Berdasarkan Tabel 4.1 hingga Tabel 4.5 terlihat bahwa sistem informasi monitoring perkuliahan dan kehadiran mahasiswa di Program Studi Pendidikan Teknik Informatika dan Komputer Jurusan Teknik Elektro Fakultas Teknik Universitas Negeri Jakarta dilakukan pengujian menggunakan pengujian black box.

Jadi, berdasarkan apa yang telah dievaluasi dan diuji oleh pengguna dapat dilihat bahwa hasil pengujian sesuai dengan perancangan kebutuhan fungsional sistem dan tampilan sistem. Maka dapat dipastikan bahwa pengujian fungsional sistem sudah sepenuhnya bekerja sesuai dengan yang diharapkan pihak Jurusan Teknik Elektro telah layak digunakan user sesuai dengan hasil pengujian yang telah dilakukan.

\section{Kesimpulan dan Saran}

Berdasarkan hasil penelitian pendahuluan, hasil pengembangan produk, hasil pengujian pengujian dan revisi produk serta pembahasan yang telah dipaparkan sebelumnya maka dapat ditarik kesimpulan sebagai berikut:

1. Hasil dari penelitian pengembangan ini adalah sebuah produk, yaitu sistem monitoring perkuliahan dan kehadiran mahasiswa berbasis web.

2. Proses pengembangan aplikasi sistem informasi monitoring perkuliahan dan kehadiran mahasiswa berbasis web dilakukan dengan menggunakan metode penelitian Research and Development yang digabungkan dengan metode pengembangan perangkat lunak prototype.

3. Metode pengembangan perangkat lunak menggunakan prototype dengan tahapan requirements definition, analysis atau design system, implementasi, dan testing system, dimana requirements definition disesuaikan dengan analisis kebutuhan di Program Studi Pendidikan Teknik Informatika dan Komputer Jurusan Teknik Elektro Fakultas Teknik Universitas Negeri Jakarta.

4. Berdasarkan pengujian dengan black box menunjukkan bahwa situs sistem monitoring perkuliahan dan kehadiran telah berjalan dengan baik, dimana sistem dapat memberikan informasi mengenai monitoring daftar hadir perkuliahan dosen, kehadiran perkuliahan, tugas, rumusan penilaian dan penilaian secara rinci.

\section{Daftar Pustaka:}

${ }^{[1]}$ Arikunto, Suharsimi. 2001. Dasar-dasar evaluasi pendidikan (Edisi Revisi). Jakarta: Bumi Aksara.

${ }^{[2]}$ Kementerian Pendidikan Nasional. 2009. Peraturan Menteri Pendidikan Nasional Nomor 61 Tahun 2009 tentang Pemberian Kuasa dan Delegasi Wewenang Pelaksanaan Kegiatan Administrasi Kepegawaian Kepada Pejabat Tertentu di 
Lingkungan Kementerian Pendidikan Nasional.

Jakarta: Kementerian Pendidikan Nasional.

${ }^{[3]}$ Kadir, Abdul. 2003. Pengenalan Sistem Informasi.

Yogyakarta: Andi Offset.

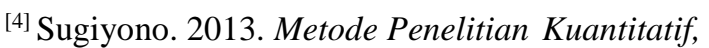
Kualitatif dan R\&D. Bandung: Alfabeta.

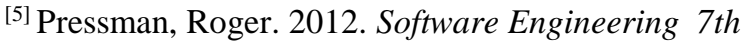
Edition. New York: McGraw-Hill. 